\title{
Comparing the Meaning Potential in Shakespeare and Manto through Speech Acts:
}

\section{A Discourse Pragmatic Study}

\author{
${ }^{a}$ Tazanfal Tehseem, ${ }^{b}$ Muazzma Batool, ${ }^{c}$ Aqsa Arshad , ${ }^{d}$ Zohaib Hassan \\ ${ }^{a}$ Assistant Professor at the Department of English, University of Sargodha, Pakistan \\ Email: tazanfal.tehseem@uos.edu.pk \\ ${ }^{\mathrm{b}}$ Research scholar at the Department of English, University of Sargodha, Pakistan \\ Email: muazzmab@gmail.com \\ ${ }^{\mathrm{c}}$ Research scholar at the Department of English, University of Sargodha, Pakistan \\ Email: aqsaarshad648@gmail.com \\ ${ }^{\mathrm{d}}$ Research scholar at the Department of English, University of Sargodha, Pakistan \\ Email: zohaib_hassan2656@yahoo.com
}

\begin{tabular}{l} 
ARTICLE DETAILS \\
\hline History: \\
Accepted 10 August 2021 \\
Available Online September 2021
\end{tabular}

\section{Keywords:}

Speech Act, Felicity Condition, Soliloquies, Hamlet, Keshulal

Singh, Manto

\section{JEL Classification:}

E69, E69

DOI: $10.47067 /$ real.v4i3.176

\begin{abstract}
This paper attempts to explain the application of speech act theory (John Searle, 1976) on the soliloquies expressed by Hamlet and Keshulal Singh. The descriptive focus of this study is to draw attention to the felicity conditions whether they are being fulfilled by the speakers while making an utterance or not. Content analysis based on speech act theory is used for this paper. It has been pointed out that declaratives are less while directives are more applicable on these soliloquies, with the help of analysis. Hamlet and Keshulal's inner self is being depicted through their speeches and it is analyzed that they are so much upset and are in the situation of to be or not to be that they do not know what should be their strategies, in taking their revenge. In actuality, they are trying to extinguish the storm which is bursting inside them through their soliloquies but by comparing the inner devastation of both characters. It is highlighted that Hamlet's soliloquies are more self-explanatory than that of Keshulal because Hamlet makes vows, questions, deplores, and challenges the circumstances more than the Keshulal.
\end{abstract}

(C) 2021 The authors. Published by SPCRD Global Publishing. This is an open access article under the Creative Commons AttributionNonCommercial 4.0

Corresponding author's email address: tazanfal.tehseem@uos.edu.pk

\section{Introduction}

Language, according to Halliday and Matthiessen (1999), is typified as a multidimensional structure of the $4^{\text {th }}$ degree of intricacy inside a hierarchical taxonomy of subsystems, "mortgaging" traits to reduced structures by which it manifests. Language is now an elevated interpretative entity in that it is capable of both hauling and constructing meanings, and that is the rudimentary attribute of primordial semiotic mechanisms. Language, besides different sub-systems, is, therefore, a regime and an embodiment. And both are inanimate entities but primarily diverse spurts of a single paradigm that 
extends from potential toward manifestation across a spectrum of emulation. So, it is to assert that whilst the acts of a connotation constitute the discourse erupting in period initialize a meaning potential, acknowledging that these are two distinct cycles of language also as nuance commodity: acts epitomize potential, and potential arises from acts, though since the linguistic essential concern is that it is an asset besides constructing meaning. And that is where one can uncover facts Whenever occurrences are refined in to the potential further upstream all across the spectrum of emulation, enlightenment occurs.

This research paper intends to analyze the speech acts (Searle, 1976) and felicity conditions which play a vital role in communication aiming to foreground pragmatics as a chief contributor to the credible power of human communication in a context. Leech (1987) is of the view that pragmatics studies the meaning of utterances in their context. Brown and Yule (1983) endeavor to elucidate that in pragmatics, meanings depend on their context. In Levinson's (1983) view, the connection between language and context is called pragmatics as language and context are indivisible and in this way, context affects the meaning of language or utterance used by the speaker. As a result, different elucidations are made by the hearer due to different contexts. Inspired by the above perspectives, the study aims at digging deeper in to the selected characters, i.e. Hamlet and Keshulal Singh.

The paper peruses the content analysis based on the use of the speech acts proposed by Searle (1976) in process of analyzing data. It aims to explore that all speech acts are applicable on selected soliloquies and the most occurring act is directive one while the least use is that of declaratives. The findings are explicated through the tables given below. It is realized that the directive speech act is mostly used in these soliloquies because the speakers want to get rid of the turmoil inside them by making requests and questions to themselves. This research paper has been implemented on the following research questions.

1. Does the unconscious desire influence Hamlet and Keshulal Singh's minds?

2. What speech acts are being implied by both Hamlet and Keshulal in their soliloquies?

3. Whether the selected characters are following felicity conditions in their soliloquies or not?

\section{Speech Act and Stance Projection in Hamlet and Manto Kay Afsanay}

Speech act theory deals with the effect of utterances on the hearer and the speaker's behavior (Crystal, 1997). The prior studies reveal that Jaee (2015) applies Freud's model of psychoanalytic theory on the soliloquies used in Macbeth and concludes that the id overcomes Macbeth's superego and leads his life towards destruction. Premised on the same framework, Firouzjaee and Pourkalhor (2014) diagnose the soliloquies used in two Shakespearean plays and made the point that id dominates superego in one play while the opposite result comes for the other one. Working on the same theoretical framework, Chiu (2012) sheds light on the soliloquies of five Shakespearean plays and assumes that Shakespearean characters are the victim of Oedipus complex but Murphy (2007) concentrates on soliloquies in twelve Shakespearean plays through corpus stylistic analysis and finds that soliloquies used in comedies are about relationship and love; in tragedies, they talk about the supernaturalism and religion; and in historical plays, the characters seem to contemplate themselves. Yinghui (2015) explored the character of Hamlet from the viewpoint of his inner mind changes and reveals that one must not let the opportunities go away. Also, Alam (2015) attempts to analyze Hamlet's soliloquies with help of some definitions of soliloquy and comes to know that soliloquies give voice to Hamlet, and Marzolae (2014) demonstrates that Hamlet delayed in taking his father's revenge just because of seeking for knowledge. Whereas, Hooti (2013) proposed that Hamlet delayed his decision of killing his uncle (Claudius) by applying Derrida's notion of deconstruction. Further, Gurcu (2014) interpreted 
Hamlet's $4^{\text {th }}$ soliloquy in three cinematic adaptations and argues that Hamlet is eternal. On psychoanalysis, Kubresli (2013) predicts that to get rid of suffering, to get an honor, and to feel humiliation, Hamlet made his relationship to death by using the interpretation method. Maleki (2012 highlights that due to polar concepts there is the existence of some kind of reality in Hamlet's speeches. Al-Ogaili (2012) provided strong empirical support for Hamlet's spiritual crisis and complex mental state by analyzing his character in the light of his soliloquies. Whereas, Carroll (2010) sums up that Hamlet is a modern character who is suffering from pain, hardships, hurdles, etc. Shibuya (2004) views Hamlet as a performer, who performs many acts through his dialogues. Kirsch (1981) describes Hamlet's sadness whereas, this article is motivated by a pragmatic approach to the study of language with the major focus on conversational context, Searle's (ibid) model of speech act theory, and felicity conditions on the selected works of Shakespeare and Manto.

\section{Research Methodology}

This research is built on the framework of John Searle's (1976) model of speech act theory. The methodological framework scrutinizes Hamlet's soliloquies and Keshulal's soliloquy. The singled out data comprises 197 selected clauses. For implicature, the soliloquies were being read and categorized into clauses by the researchers, and it has been pointed out that whether speech acts are applicable or not, and if are then how do they fit on research questions' garment. It has also been highlighted that whether the felicity conditions have been flouted or followed by the characters. Secondly, the data have been carefully picked out of the selected text, and then have been analyzed and arranged properly. During the process of data analysis, speech acts have been applied one by one. Finally, the results have been meticulously evaluated and revealed.

The content analysis based on the speech act theory (ibid) has been applied in this research paper. This study aims to examine and construe the data and make a portrayal of speech acts on Hamlet and Keshulal's soliloquies and to explicate whether the speakers have followed felicity conditions or not. Content analysis or textual analysis is a methodology in social sciences that concerns the study of the content of communication and subjecting the data attained from descriptive analysis to a deeper level inspires content analysis (Yildirim and Simsek, 2005).

\section{Theoretical Background}

Haberland and Mey (1977) state that pragmatics concerns with the study of the science of language use or language in action. Therefore, Crystal (1997) has indicated that the effect of utterances on the behavior of hearer and speaker are considered in speech act theory. In linguistic pragmatics, the central phenomenon in speech act theory is presupposition through implicates. Following the same, Austin (1962) distinguished performatives (true utterances) and constatives (statements that express information and can be true/ false). Searle (1976) further divides illocutionary acts into five types of utterance which are explained below, and those are the focal point of this paper.

- Representatives deal with the expression of true proposition by speaker e.g. asserting, affirm, report, believe, concluding, etc.

- Directives concern with the efforts by the speaker to get the audience to do something e.g. requesting, questioning, challenging, commanding, insisting, etc.

- Commissives talk about the attempts by the speaker for future course of action. For example, threatening, offering, pledging, promising, swearing, guarantee, vowing etc.

- Expressives express the psychological state of mind of the speaker. For instance, thinking, congratulating, thanking, condolence, deploring, welcoming, apologizing, etc. 
- Declaratives instantaneously change the environment. It alters the exterior environment of a situation by producing an utterance e.g. ex-communication, to christen somebody, declaration of war, etc.

In short, all utterances express propositions as well as perform an action in which the privileged level of action is called a speech act. The definite set of felicity conditions provides a suitable characterization of illocutionary force. John Searle (1969) classifies felicity conditions into "Propositional Content" (that limited the restrictions on content), "Preparatory Conditions" (that dealt with real-world preconditions to each illocutionary act), "Sincerity Conditions" (that explicated the requisite intention, feelings, and beliefs of the speaker) and "Essential Conditions". The specification of content is compulsory for supplying felicity conditions to some illocutionary acts.

\section{Data Analysis and Interpretation}

The study applies speech act theory (Searle, 1976) to Hamlet and Keshulal's soliloquies. Our focus is on two dimensions: acceptation or rejection of felicity conditions and application of speech act theory on Hamlet and Keshulal's soliloquies.

\section{Table 1.The Frequency of Speech Acts in Hamlet's1st soliloquy}

\begin{tabular}{|l|l|l|l|l|l|}
\hline $\begin{array}{l}\text { Clause } \\
\text { Number }\end{array}$ & $\begin{array}{l}\text { Act: } \\
\text { Representative }\end{array}$ & $\begin{array}{l}\text { Act: } \\
\text { Directive }\end{array}$ & $\begin{array}{l}\text { Act: } \\
\text { Commissive }\end{array}$ & Act: Expressive & Act: Declarative \\
\hline $1-24$ & 3 & 2 & 1 & 17 & 1 \\
\hline
\end{tabular}

The $1^{\text {st }}$ soliloquy has expressed the extent of Hamlet's inner conflict before any revelations made by the ghost. The revelation of Hamlet's shock, because of his mother's marriage to his uncle, is revealed in this soliloquy and it is the crux of his exaggerated melancholy. At this time, he is feeling the existence of an evil that he cannot explain. He displays all characteristics of his sadness and despises himself because of an unfaithful mother's son. He thinks that he has neither control over himself, nor his surroundings and in this way despises his life and wishes that he were dead in order to get rid of humiliation and to save his honor as Kubresli (2013) examined. Neither he can change the situation, nor can accept it. He attempts to indicate that he must be silent to increase his despair, anger, and frustration. Felicity conditions are being followed in this soliloquy.

His beliefs about religion are shattering when he asserts and gives a somewhat guarantee in lines (131-136) that "solid flesh would melt, thaw and resolve" (Shakespeare, 2004, p.19), "Everlasting had not to fix'd" (ibid) and all laws are "weary, stale, flat, and unprofitable" (ibid). He expresses his situation through these words that there is no fixity in the laws of the Bible when he sees the hasty marriage of his mother and uncle. Everything in the universe seems flat, unprofitable, and weary to him because of his inner turmoil. He uses representative and commissive speech acts in the former line while the only representative is being used in the case of the second line mentioned above. The verb "seem" expresses his inner thought.

He deplores the marriage of his mother and his uncle in lines (137-139) by calling it "an unweeded garden" (ibid) and says that the fruit of this garden is "rank and gross in nature" (ibid) which means that the result of their marriage is not profitable rather it is disgusting and coarse one. It is because of this marriage that Hamlet is too much frustrated and does not know how to explain such a condition and for this Carroll (2010) calls him a modern character (full of frustration, sadness, 
shallowness, etc.). He uses expressive speech acts by using the verbs such as: "fie", "fie", "grows" and "possess" (ibid).

In lines (139-144), he reports that his father dies only two months before the marriage of his mother and uncle, and before his death, he was "so excellent a king" (ibid), "Hyperion to a satyr" (ibid) and "loving to my mother"(ibid). But all this affection was pretension because only two months have passed since his father's death and his mother has forgotten everything about him and hurries to marry her (husband's) brother. He believes that his father might not allow the "winds of heaven visit her face too roughly" (ibid) which means that his father might not permit his mother to marry a Satyr, his rival, and a villain. He deplores this situation through the following verbs: "come" and "might not beteem". (ibid)

Lines (144-159) indicate the directive and expressive speech acts. Hamlet makes a question to himself ("Must I remember?" (ibid)), that whether he should remember this incident or not. He is too much upset that why has the appetite of lust increased too much within a month to her mother that she hastily marries his brother-in-law to feed this lust? ("Why, she would hang on him,...”(ibid)). He expresses his situation by using the verbs like "hang", "grown" and "fed on" (ibid). When he cannot overcome the situation, he requests to his body that "Let me not think on't:..."(Shakespeare, 2004, p.20). He deplores the present condition that my mother is going to marry a person and expresses his inner self that "Frailty" (ibid) is in woman's nature and she "wants discourse of reason"(ibid).

He calls his mother "a beast" (ibid) on whose "galled eyes" (ibid) "the salt of most unrighteous tears" (ibid) and she marries suddenly to a person who is "no more like my father" (ibid). He condemns this condition when he used the verbs such as: "mourn'd", "left" and "married" (ibid) (in 2 clauses). In lines (159-160), he mourns the present situation that how wickedly she speeds up to post with such deftness to incestuous sheets.

Lines (161-162) express the present situation that this marriage has broken his heart. He is falling into the disease of depression that what has happened in actuality is not believable. He does not know how to cope with the situation, how to face reality. He has decided that he should manipulate the situation by holding his tongue "I must hold my tongue!" (ibid). He asserts that this marriage cannot "come to good" (ibid). He declares that this thing has broken "my heart" (ibid). Thus this soliloquy tells us about Hamlet's inner conflict through the usage of the expressive, directive, commissive, declarative, and representative speech acts.

Table 2.The Frequency of Speech Acts in Hamlet's 2nd soliloquy

\begin{tabular}{|l|l|l|l|l|l|}
\hline $\begin{array}{l}\text { Clause } \\
\text { Number }\end{array}$ & $\begin{array}{l}\text { Act: } \\
\text { Representative }\end{array}$ & Act: Directive & $\begin{array}{l}\text { Act: } \\
\text { Commissive }\end{array}$ & Act: Expressive & $\begin{array}{l}\text { Act: } \\
\text { Declarative }\end{array}$ \\
\hline $1-15$ & 3 & 6 & 5 & 2 & 0 \\
\hline
\end{tabular}

In this soliloquy, the speaker expresses his anger, excitement, and resolution by requesting his physical parts to bear witness to his strategies to preserve composure. His questions and requests in lines (98-101) "O all you host of heaven! O earth!” (Shakespeare, 2004, p.46), and "O, fie! Hold, hold, myheart; / And you my sinews, grow not instant old, / But bear me stiffly up!” (ibid) designate that he is directing his outer body to help him in getting his aim which is to take revenge of his father. He 
appeals to his body to not grow old and make him strong so that he can fulfill his wish. In lines (101103), he makes a vow to the ghost that he will "Remember thee!"(ibid) in his "distracted globe" (ibid). He promises that he will not let his father's recollection away from his mind through the verb "holds" (ibid).

In lines (103-110), he promises the ghost of his father that he will "Remember thee!" (ibid) and erase all "trivial fond records" (ibid), "saws of books" (ibid), "forms" (ibid), "pressures past" (ibid) that "youth and observation" (ibid) have copied there and he swears that his "commandment" (ibid) shall be alive in his brain pure from "baser matter" (ibid). He is in a situation to do anything for his father because he is too much impressed by the abrupt death of his father, the quick marriage of his mother, and the arrival of his father's ghost for appealing hiss on to take his revenge. Hamlet now makes up his mind to take revenge.

He abhors his uncle and mother in lines (111-118) by saying that in his memory he has set his mother as a "most pernicious woman" (ibid) and his uncle as a "smiling, damned villain" (ibid). The speaker criticizes his stepfather and mother with the help of the verbs ("set" and "smile" (ibid)) and bids farewell to his downheartedness in line 117 “'Adieu, adieu!” (ibid). He changes his entire confusion by declaring his motto and swearing that he will retaliate when he says "I have sworn't" (ibid). The felicity conditions are not violated in the entire soliloquy.

\section{Table 3.The Frequency of Speech Acts in Hamlet's $3^{\text {rd }}$ soliloquy}

\begin{tabular}{|l|l|l|l|l|l|}
\hline $\begin{array}{l}\text { Clause } \\
\text { Number }\end{array}$ & $\begin{array}{l}\text { Act: } \\
\text { Representative }\end{array}$ & $\begin{array}{l}\text { Act: } \\
\text { Directive }\end{array}$ & $\begin{array}{l}\text { Act: } \\
\text { Commissive }\end{array}$ & Act: Expressive & $\begin{array}{l}\text { Act: } \\
\text { Declarative }\end{array}$ \\
\hline $1-44$ & 8 & 17 & 8 & 3 & 9 \\
\hline
\end{tabular}

This soliloquy displays the psychological expression of the speaker (when he finds out his struggles for the performance of a play (The Murder of Gonzago)). He is conveying his inner self when he says that he is a knave and coward who is unable to explicate his emotions whereas the player is courageous who can execute an imaginary situation as factual. What he is thinking about his strategies for revenge, the ghost, and his uncle in actual he is expressing his inner self like King Lear. All speech acts are applicable to this soliloquy. The felicity conditions are accepted in the entire soliloquy except for the lines (599-604) where he is in that situation that he is not certain about the nature of his uncle and ghost while in view of Croddy (2002), there must be two essential conditions for action: 1) the speaker is accountable for satisfying a promise which is the consequence of his / her performance and 2) the audience should rightly believe about the speaker's intent.

He bids goodbye to all and proclaims that now he is "alone" (Shakespeare, 2004, p.90) in line 552. In line 553, he calls himself a "rogue" (ibid) and "peasant slave” (ibid) who has no courage to extinguish his thirst. He makes a question to himself that is it possible to "force" (ibid) to make all his uncle's "visage wann'd" (ibid) "tears" (ibid), "distraction" (ibid) into a "broken voice" (ibid) through his play which he is going to play to check his uncle's reaction in lines (554-560). Lines 560 and 561 demonstrate that it makes no difference to his mother what he is going to do because unlike Hecuba (who truly loves her husband) her mother does not have any true affection for her husband. He again makes questions in line (562-565) that what was the relation between Hecuba and her husband? Do the 
players have "the motive and the cue for passion" (ibid) that he has? In actual he wants to say that whether the passion he has can be communicated by players or not.

He then makes a promise in lines (565-569) that through his actions the player will be able to "drown the stage with tears" (ibid), to "cleave" (ibid) the audience' ear with speech, to "make mad the guilty" (ibid), "appall the free" (ibid), "confound the ignorant" (ibid) and "maze" (ibid) the very "faculties eyes and ears" (ibid). He says that it is the player who can manipulate the situation, unlike speaker who is a (lines (566-571) "dull" (Shakespeare, 2004, p.91) and "muddy-mettled rascal" (ibid) who can say nothing. He is much frustrated in the present condition and in this way makes questions to himself in lines (571-575) that whether he is a "coward" (ibid)? Who darest o call him a "villain" (ibid), break his "pateacross" (ibid) plucks off his "beard and blows" (ibid) in his face, and pinch him by the nose?

In lines (576-589), the speaker takes an oath that he should take revenge now and then suddenly alters his mind by calling himself a "pigeon-liver'd" (ibid) and "lackgall” (ibid). He expresses his anger by saying that he should fat the insects with "this slave's offal" (ibid). He condemns his uncle by using the words like a "Bloody", "bawdy", "remorseless”, "lecherous”, "kindles”, and "treacherous” (ibid) villain. He discourses that he is an ass while the player is brave than him and then abruptly swears that he has decided to take revenge which is shown by clauses like "prompted to my revenge" (ibid), "unpack my heart with words" (ibid) and "falla-cursing" (ibid).

He announces in lines (589-595) that his mother and uncle ("guilty creatures" (ibid)) are sitting in this play and "the very cunning of the scene" (ibid) will immediately strike their soul and they proclaim "their malefactions;/ For murder..."(Shakespeare, 2004, p. 92). He explicates that although the expressions have no tongue yet they will speak "With miraculous organ" (ibid). He pledges in lines (595-599) that players will play something like the murder of his father before his uncle and the speaker will scrutinize his looks and "tent him to the quick" (ibid). He further tells that if his uncle flinches during this phenomenon then he gets success.

He again feels cowardliness in lines (599-604) that the ghost "may be the devil" (ibid) who wants to get benefit from his melancholy and weakness to damn him. Then once again he makes a vow in lines (604-6o6) that the speaker will catch the "conscience of the king" (ibid) through the play. The speaker is aiming at investigate the actual condition of the present king that whether his uncle killed his father or not, employing the performance of the play. Hamlet performs many acts in this soliloquy as Shibuya (2004) concludes in a study.

\section{Table 4.The Frequency of Speech Acts in Hamlet's $4^{\text {th }}$ soliloquy}

\begin{tabular}{|l|l|l|l|l|l|}
\hline $\begin{array}{l}\text { Clause } \\
\text { Number }\end{array}$ & $\begin{array}{l}\text { Act: } \\
\text { Representative }\end{array}$ & Act: Directive & $\begin{array}{l}\text { Act: } \\
\text { Commissive }\end{array}$ & Act: Expressive & Act: Declarative \\
\hline $1-33$ & 9 & 14 & o & 6 & 4 \\
\hline
\end{tabular}

This soliloquy expresses the weary and meditative nature of the speaker rather than the angry and passionate one. He is in a situation of to be or not to be because, on one hand, he wants to take revenge while on the other hand, he is afraid of being the culprit because it is against both rules of society and religion to murder someone illegally. 
He is trying to direct his outer body when he questions himself that whether he should content with his fate or commit the murder of his victim? Who will bear the wrongs, evils, and calamity of this world? Here directive speech act is being used in lines (63-67) when he is in a topsy-turvy situation and states that whether he should suffer the "slings and arrows" (Shakespeare, 2004, p.97) of disgraceful destiny. He tries to make a plan to kill his uncle but the more the plan he makes, the more he gets confused because in actual, he wants to know the truth about the murder of his father and in this way delays in making a decision or committing a murderous act as what Hooti (2013) and Marzolae (2014) conclude in their studies as well. In lines (67-71), he discloses his real decision that when he commits suicide then there will be no more "heart-ache" (ibid) and "thousand natural shocks" (ibid). After death, he will not see the "consummation" (ibid) which is devoutly wished by his mother and uncle. He wants to escape from reality and live an illusionary life because it is difficult for an ordinary man to face the bitter reality.

He again reveals his thought before us in lines (71-75) that after a death we will sleep forever and he again gets confused that may there will be any dream in that sleep. Then he makes a question that what kind of "dreams may come" (ibid) in this sleep. He transforms his thought once again and exposes that when we leave "this mortal coil" (ibid) then there come no more dreams and one can get soothe in death. Lines (75-83) disclose the speaker's love for death when he says that there are calamities in this universe and he longs to go to the immortal world. He directs himself when he is much tense that when he commits suicide "With a bare bodkin" (Shakespeare, 2004, p.98) then who will bearthe "whips and scorns of time”, "law's delay", "pangs of despised love”, "oppressor's wrong”, "the proud man's contumely", "the spurns" and "insolence of office" (ibid) that patient merit of the undeserving takes. He wants to say that he will get the release from all tensions, calamities, hardships, and frustration of the world in the sleep of death.

In lines (83-89), he expresses his perplexity that although it is difficult to bearthe hardships of life these hurdles are better than those of the "undiscover'd country" (ibid) from where no voyager returns. He explicates that the very condition of death "puzzles the will" (ibid) and compels us to bear these "ills" (ibid) which we have in this world rather than to "fly to others that we know not of" (ibid). At one moment he wants to escape from this world but in the next moment, he longs to return. He is feeling disturbance that where should he go? What should he do? He is disclosing whatever is going on in his unconscious. This indicates the true present situation of the speaker through his expression.

Lines (90-95) indicate that it is our "conscience" (ibid) that makes us "coward" (ibid), suspend our "action" (ibid), and break our "resolution" (ibid). Unconsciously he wants to commit suicide while consciously he yearns to remain in the destruction of the present world and can be called an immortal character as what Gurcu (2014) calls him. Lines (95-97) show his request to Ophelia to remember him in her prayers as fair Ophelia in her "orisons/ Be all my sins remember'd" (ibid). All speech acts are applicable to this soliloquy except the commissive one. Like the above soliloquies, felicity conditions are not flouted by the speaker here.

Table 5.The Frequency of Speech Acts in Hamlet's $5^{\text {th }}$ soliloquy

\begin{tabular}{|l|l|l|l|l|l|}
\hline $\begin{array}{l}\text { Clause } \\
\text { Number }\end{array}$ & $\begin{array}{l}\text { Act: } \\
\text { Representative }\end{array}$ & $\begin{array}{l}\text { Act: } \\
\text { Directive }\end{array}$ & $\begin{array}{l}\text { Act: } \\
\text { Commissive }\end{array}$ & Act: Expressive & Act: Declarative \\
\hline $1-14$ & 1 & 8 & 2 & 3 & 0 \\
\hline
\end{tabular}


The $5^{\text {th }}$ soliloquy shows the transformation in Hamlet because he does not want to torture his soul more rather than wants to kill his stepfather. He is trying to decide to kill his uncle at this "witching time of night" when the churchyards "yawn", and the hell "breathes out" (Shakespeare, 2004, p.126-127) in lines (375-377). He asks himself in lines (377-379) that can he "drink hot blood" (Shakespeare, 2004, p.127) of his uncle? i.e. to kill him at this time so that the day can "quake to look on" (ibid). It means that he wants to murder in such a horrible way which can become the source of people's horrification after seeing it. In line 397, he declares that he will be "soft" (ibid) to his mother now.

He wants to use some tools like harsh words for teasing his mother rather than any action because he does not want to be unnatural to her like Nero (who killed his mother). He neither wants to release his mother totally nor to be so much ferocious to her. He requests his heart that loses not his "nature" (ibid) and "Let me be cruel, not unnatural" (ibid) in lines (380-382). He makes a vow in lines (383-386) that he will soothe his soul not by using any dagger but by speaking harsh words to his mother when he says that he will speak "daggers to her, but use none" (ibid). His tongue and soul will be "hypocrites" (ibid). At the end of this soliloquy, he explains that he will not stop his tongue to condemn her. He expresses his complex mental state as what Al-Ogaili (2012) concludes as well. All speech acts (except the declarative one), as well as felicity conditions, are being followed in this soliloquy.

Table 6.The Frequency of Speech Acts in Hamlet's $6^{\text {th }}$ soliloquy

\begin{tabular}{|l|l|l|l|l|l|}
\hline $\begin{array}{l}\text { Clause } \\
\text { Number }\end{array}$ & $\begin{array}{l}\text { Act: } \\
\text { Representative }\end{array}$ & Act: Directive & $\begin{array}{l}\text { Act: } \\
\text { Commissive }\end{array}$ & Act: Expressive & Act: Declarative \\
\hline $1-26$ & 4 & 11 & 1 & 8 & 2 \\
\hline
\end{tabular}

In this soliloquy, the speaker has postponed his intention to slay his prey because he wants to take vengeance for his father who has been killed by his uncle when his father was in his depraved situation. While in lines (76-78), the speaker speaks to himself that it is easy to take revenge now because his uncle is offering prayer but he does not want to commit his murder in this condition so that, like the speaker's father, his uncle too should not go to heaven. He wants to accomplish his yearning in this way because he thinks that there must be justice in revenge.

He contemplates at the present situation in lines (78-82) that this "villain kills my father" (Shakespeare, 2004, p.131) and I am trying to send "this same villain" (ibid) to heaven by killing him while offering prayer and considers his this action "hire and salary, not revenge" (ibid). Lines (83-90) express his decision that he will never retaliate in these circumstances because he has taken his father "grossly full of beard" (ibid) with all his sins "broad blown" (ibid) as blush as the month of May. He declares this decision when he says "No" (Shakespeare, 2004, p.132) i.e. he will never do so now.

In lines (91-98), he gives commands to his sword that it should take action when his uncle is "drunk asleep" (ibid) or "in his rage" (ibid) or in the "incestuous pleasure of his bed" (ibid), or "at the game" (ibid), or "a-swearing" (ibid), or "about some act" (ibid) that has no savor of "salvation" (ibid). He wants to do this so that his step father's soul should be as ruined and black as "hell” (ibid). Lines (98-99) indicate that it is because of the prayer of the speaker's mother that he "prolongs thy sickly days" (ibid). All speech acts and felicity conditions are observed in this soliloquy. 
Table 7.The Frequency of Speech Acts in Hamlet's $7^{\text {th }}$ soliloquy

\begin{tabular}{|l|l|l|l|l|l|}
\hline $\begin{array}{l}\text { Clause } \\
\text { Number }\end{array}$ & $\begin{array}{l}\text { Act: } \\
\text { Representative }\end{array}$ & Act: Directive & $\begin{array}{l}\text { Act: } \\
\text { Commissive }\end{array}$ & Act: Expressive & $\begin{array}{l}\text { Act: } \\
\text { Declarative }\end{array}$ \\
\hline $1-28$ & 17 & 9 & 2 & o & 2 \\
\hline
\end{tabular}

His expression is mature in this soliloquy, unlike the previous ones. He directs himself that what is a man whose purpose of life is just to sleep and feed? Why am I so much coward despite having cause, will, power, and means to take revenge? He attempts to believe that if I can do something, I must utilize it. He is trying to strengthen his thought in this soliloquy when he expresses how the king of another country commits a war to get a little plot. He challenges and promises himself that from now onwards his thought will be bloody.

He directs himself by making a question in lines (34-37) that "How all occasions do inform against me" (Shakespeare, 2004, p.158-159) and "spur my dull revenge" (ibid) i.e. how does everything become a hurdle in his resolution? Why does he fail everytime? What kind of person he is who cannot fulfill his father's desire despite having the strength to do this? He expresses his view in lines (37-48) that it is God who born us with the capability of the reason that we should think before doing any act. Now he is not sure whether it is the "bestial oblivion" (Shakespeare, 2004, p.159) or "some craven scruple" (ibid) that he is postponing his action. Then again he explains that he has a thought which "quarter'd, hath" (ibid) but one part "wisdom" (ibid) and three parts "coward” (ibid). He regrets his situation that why he is delaying in taking action when he has "cause" (ibid), "will" (ibid), "strength" (ibid), and "means" (ibid) to perform the task.

He tries to inspire himself to throw out cowardliness by quoting the example of a king (where the army of such charge and mass is led by a "delicate and tender prince" (ibid)) who girds up his lions to take his act on a trivial matter considering it a great matter in lines (48-58). Lines (58-68) express his resolution to act and he declares, makes a promise, and challenges that by this time forth his thoughts "be bloody, or be nothing worth!" (Shakespeare, 2004, p.159-160). He explicates that the reason for his case (whose "father kill'd, a mother stain'd" (ibid)) is greater than that of the king who is going to fight merely for a plot. Thus this soliloquy fulfills felicity conditions and all speech acts except the expressive one. 
Speech Act Analysis: Keshulal's Soliloquy

\begin{tabular}{|c|c|c|c|c|c|c|}
\hline Text & Clause & $\begin{array}{l}\text { Act: } \\
\text { Rep }\end{array}$ & $\begin{array}{l}\text { Act: } \\
\text { Dir }\end{array}$ & $\begin{array}{l}\text { Act: } \\
\text { Com }\end{array}$ & $\begin{array}{l}\text { Act: } \\
\text { Exp }\end{array}$ & $\begin{array}{l}\text { Act: } \\
\text { Dec }\end{array}$ \\
\hline 1. & 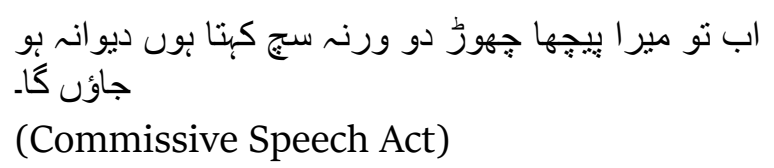 & & & $\mathrm{X}$ & & \\
\hline 2. & 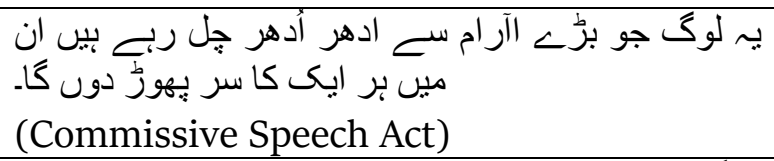 & & & $\mathrm{X}$ & & \\
\hline 3. & 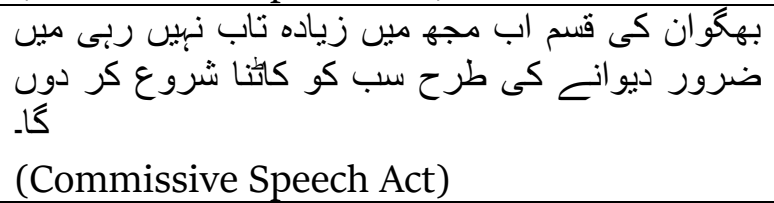 & & & $\mathrm{x}$ & & \\
\hline 4. & 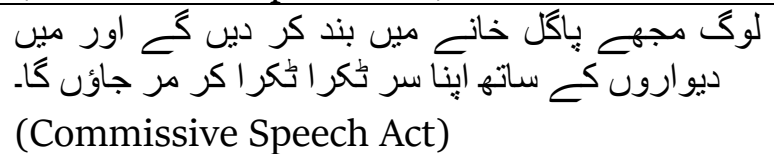 & & & $\mathrm{x}$ & & \\
\hline 5. & 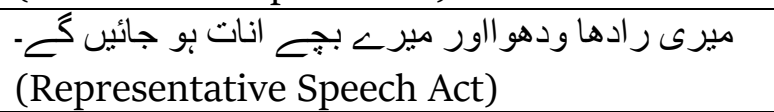 & $\mathrm{X}$ & & & & \\
\hline 6. & 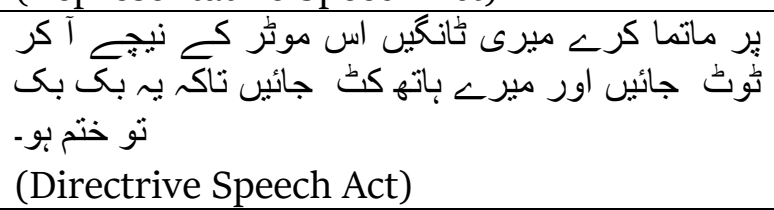 & & $\mathrm{x}$ & & & \\
\hline 7. & 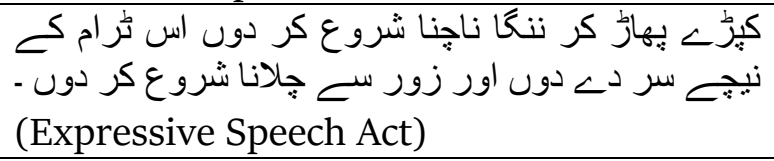 & & & & $\mathrm{x}$ & \\
\hline 8. & $\begin{array}{l}\text { "ن كرونكياكياكرون" } \\
\text { (Directive speech act) }\end{array}$ & & $\mathrm{X}$ & & & \\
\hline
\end{tabular}

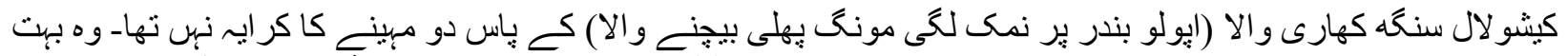

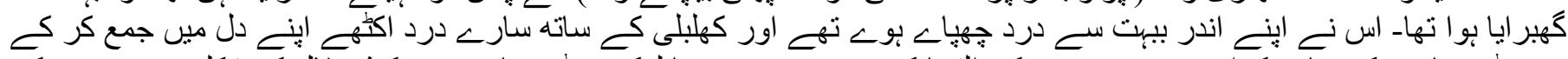

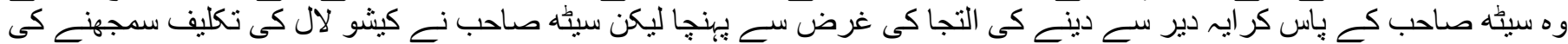

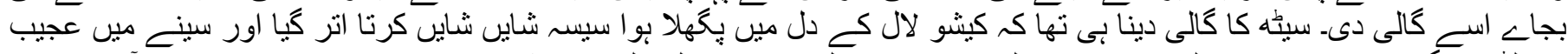

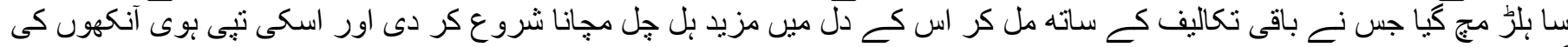

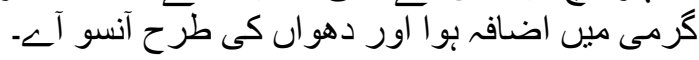

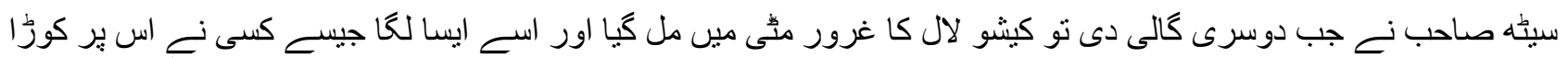

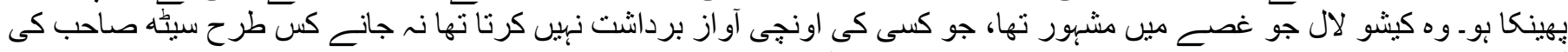

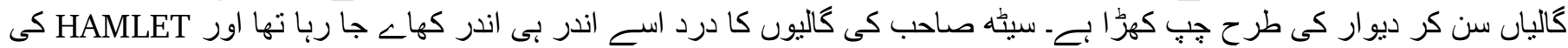

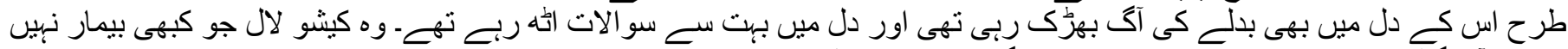

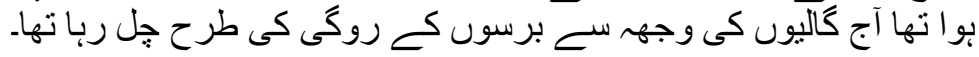

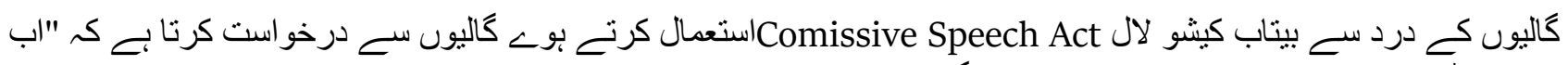

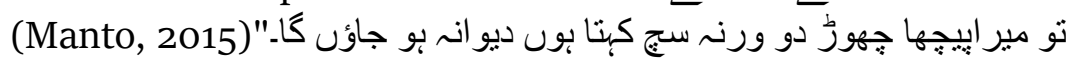

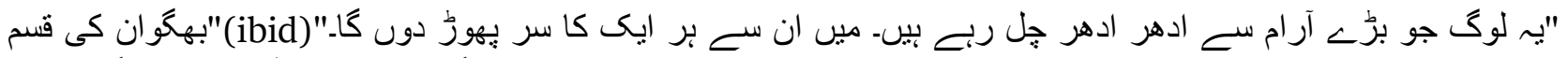

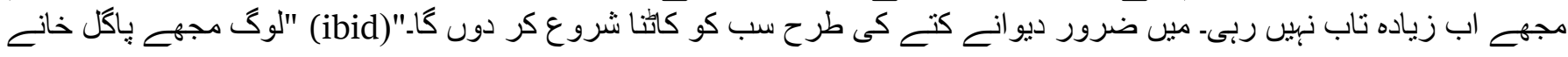




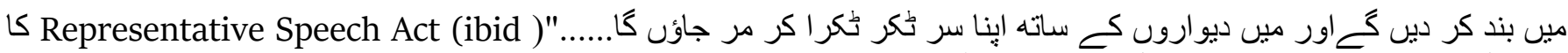

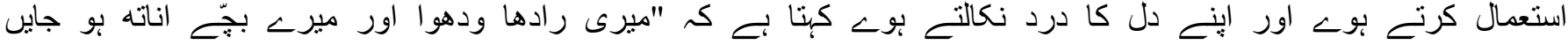

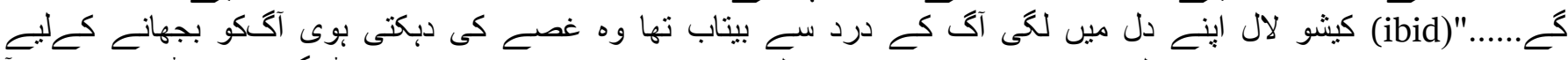
Sirectve Speech Act

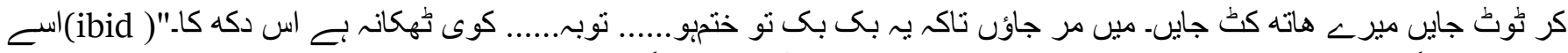

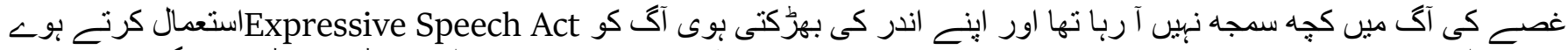

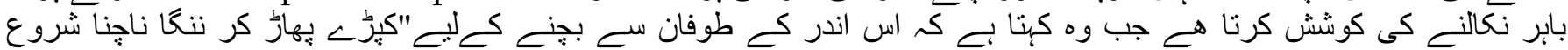

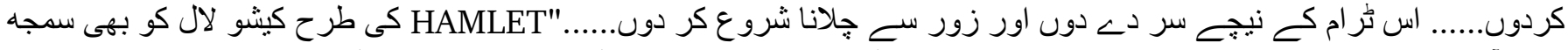

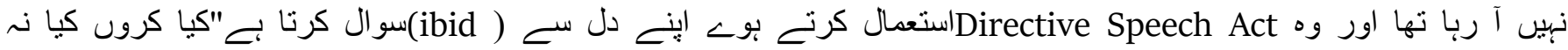

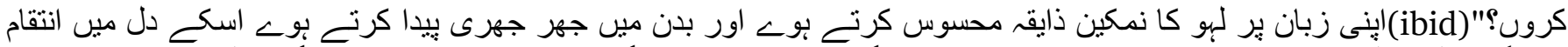

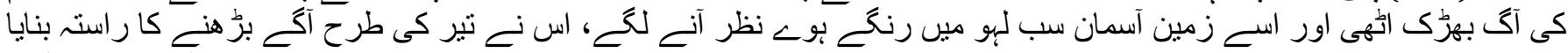

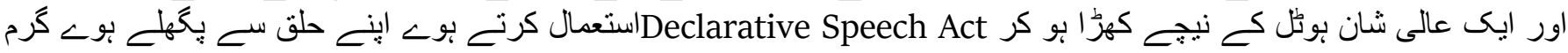

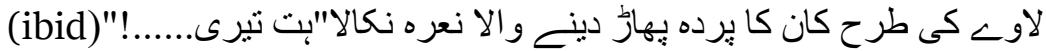

Table 8.The Frequency of Speech Acts in Keshulal Singh's soliloquy

\begin{tabular}{|l|l|l|l|l|l|}
\hline $\begin{array}{l}\text { Clause } \\
\text { Number }\end{array}$ & $\begin{array}{l}\text { Act: } \\
\text { Representativ } \\
\text { e }\end{array}$ & $\begin{array}{l}\text { Act: } \\
\text { Directive }\end{array}$ & Act: Commissive & Act: Expressive & $\begin{array}{l}\text { Act: } \\
\text { Declarative }\end{array}$ \\
\hline $1-9$ & 01 & 02 & 04 & 01 & 01 \\
\hline
\end{tabular}

\section{Findings}

\section{Table 9.The Frequency of Speech Acts in all soliloquies}

\begin{tabular}{|c|c|c|c|c|c|}
\hline $\begin{array}{l}\text { Soliloquy } \\
\text { Number }\end{array}$ & $\begin{array}{l}\text { Act: } \\
\text { Representativ } \\
\text { e }\end{array}$ & $\begin{array}{l}\text { Act: } \\
\text { Directive }\end{array}$ & Act: Commissive & Act: Expressive & $\begin{array}{l}\text { Act: } \\
\text { Declarative }\end{array}$ \\
\hline $1-$ & 03 & $\mathrm{O} 2$ & 01 & 17 & 01 \\
\hline 2- & 03 & 06 & 05 & 02 & oo \\
\hline 3- & 08 & 17 & 08 & 03 & 09 \\
\hline $4^{-}$ & 09 & 14 & $\mathrm{OO}$ & 06 & 04 \\
\hline $5-$ & $\mathrm{O} 1$ & 08 & $\mathrm{O} 2$ & 03 & $\mathrm{OO}$ \\
\hline 6- & $\mathrm{O} 4$ & 11 & 01 & 08 & 02 \\
\hline 7- & 17 & 09 & 02 & $\mathrm{OO}$ & 02 \\
\hline 8- & 01 & 02 & 03 & 01 & 01 \\
\hline Total & 46 & 69 & 22 & 40 & 19 \\
\hline Percentage & $23.36 \%$ & $35.04 \%$ & $11.18 \%$ & $20.31 \%$ & $9.65 \%$ \\
\hline
\end{tabular}

The findings indicate that the dominant type of speech act employed is a directive act which is used 69 times (35.04\%) while others are less occurring. It means that in soliloquies the speakers direct themselves for further actions, and to share their feelings, emotions, and experiences with the audience, to decrease the intensity of their frustration and to put an end to the eruption which is, waving inside them. They feel confused and disappointed so determine the course for themselves. They attempt to satisfy themselves to take revenge but feel engaged in abstract situations. The second position is of representative acts with a total number of 46 clauses (23.36\%). The report, believe, assert and conclude whatever is occurring in their unconscious and what they tell us is true to nature because they are asserting something actual which is the part of their unconscious. Expressive acts are in the third position with a total number of 40 clauses $(20.31 \%)$. Those clauses express that a conflict is occurring 
inside the speakers, they desire to act but there are some obstacles in their way which compel them to contemplate. They speak to themselves whatever is wandering in their unconscious. In the fourth position, there are commissive acts with a total number of 22 clauses (or 11.18\%). They make promises that they will punish the criminals and will eradicate evils and wrong-doers from society. The least frequent usage is that of declarative acts which are used 19 times in entire data (9.65\%). They change their defeated unconscious many times by declaring that they have prepared themselves to take revenge by expressing themselves as a coward, by giving examples of another king to themselves so that they can make their future course.

\section{Conclusion}

The analysis is based on the selected data; Hamlet (a character from Shakespeare's play Hamlet) and Keshulal Singh (a character from Manto's short story $N A^{\prime} R A$ ). The researchers conclude that all speech acts are applicable to soliloquies discussed in this paper such as representative, directive, commissive, expressive, and declarative. The most frequently used speech act is directive, the second position is of representative speech act, on the third number there is an expressive speech act, in the fourth position, there is commissive speech act and the least frequent usage is that of declaratives. The felicity conditions (see Data Analysis and Interpretation) are flouted by the speaker once in the third soliloquy while in others they are being followed as what Maleki (2012) explicates that Hamlet speaks truth in his speeches. The Directive speech act is used with the total number of 69 , representative speech act has the second place and used 46 times in clauses, the third position is of expressive speech act which occurs 40 times, commissive speech act comes on fourth number ( 22 speeches) while the last place is that of declarative which comes in the arena of clauses 19 times. These results are made with the help of the Table given above. It is summed up that in all soliloquies, the speakers try to maintain themselves to make their decision by making questions, requests, and promises on one hand while deploring the circumstances, reporting true propositions, and expressing their unconscious (i.e. the repressed desires of the speakers) on the other hand. The destructed nature of the speakers has been highlighted reflecting their bad condition and are trying to satisfy themselves one way or the other. Furthermore, it has been fore grounded that both the characters (Hamlet and Keshulal Singh) go for self-catharsis but the soliloquies made by Hamlet are more self-explanatory than that of Keshulal Singh because Hamlet makes vows, reports, asserts, questions, requests, commands, challenges, insists, thinks and deplores his inner and outer situations more than Keshulal Singh.

\section{References}

Alam, M. J. (2015). Soliloquies in Hamlet: Necessary or Unnecessary In the Context of the Play. International Journal of Novel Research in Interdisciplinary Studies, 2, 1-10.

Al-Ogaili, K.J.(2012). The Significance of Soliloquy as a Literary Technique in Hamlet. University of Kufa,1, 1-16.

Austin, J.L. (1962). How To Do Things With Words. Oxford: Oxford University Press.

Bayat, N. (2013). A study on the use of speech acts. Procedia-Social and Behavioral Sciences, 70, 213-221.

Boguslawski, A. (1983). AN ANALYSIS OF PROMISE.Journal of Pragmatics, 7, 6o7-627.

Brown, G. \& Yule, G. (1983).Discourse analysis. Cambridge: Cambridge University Press.

Carroll, J. (2010). Intentional Meaning in Hamlet: An Evolutionary Perspective. Style, 44, 230260.

Chiu, C. (2012). Freud on Shakespeare: An Approach to Psychopathetic Characters. Chang Gung Journal of Humanities and Social Sciences,5, 33-56.

Croddy, W.S. (2002). Performing illocutionary acts: an analysis. Journal of Pragmatics, 34, 1113-1118. 
Crystal, D. (1997).The Cambridge Encyclopedia of Language. Cambridge: Cambridge University Press. Firouzjaee, H. A. (2015). A Survey of Human Wickedness in Shakespeare's Macbeth. English Literature and Language Review, 1, 17-22.

Firouzjaee, H. A., \&Pourkalhor, O. (2014).Revisiting Shakespeare : A Study of Human Nature in Hamlet and Macbeth. International Journal of English Literature and Culture, 2, 214- 221.

Goldschmidt, M.M. (1998). Do me a favor: A descriptive analysis of favor asking sequences in American English. Journal of Pragmatics, 29, 129-153.

Gurcu, C. (2014). HAMLET ON DIFFERENT SCREENS.Route Educational and Social Science Journal, $1,340-351$.

Haberland, H., \&Mey, J. (1977). Editorial: Linguistics and pragmatics. Journal of Pragmatics, $1,1-12$.

Halliday, M. A. K., \& Matthiessen, C. (2006). Construing experience through meaning: A language-based approach to cognition. Bloomsbury Publishing.

Haverkate, H. (1990). A Speech Act Analysis Of Irony. Journal of Pragmatics, 14, 77-109.

Hirsh, J. (2010). The 'To be or not to be' Speech: Evidence, Conventional Wisdom, and the Editing of Hamlet. Georgia State University, 23, 34-62.

Hooti, N. (2013). William Shakespeare's Hamlet: A Deconstructive Study. International Research Journal of Applied and Basic Sciences, 4, 3903-3909.

Ilyas, S. \&Khushi, Q. (2012). FACEBOOK STATUS UPDATES: A SPEECH ACT ANALYSIS. Academic Research International, 3(2), 500-507.

Kirsh, A.(1981). Hamlet's Grief. The Johns Hopkins University Press, 48, 17-36.

Kurzon, D. (1998). The speech act status of incitement: Perlocutionary acts revisited. Journal of Pragmatics, 29, 571-596.

Leech, G.N. (1987). A Linguistic Guide to English Poetry. London: Longman.

Levinson, S.C.(1983). Pragmatics. Cambridge: Cambridge University Press.

Maleki, N. (2012). The Paradigm Examples of Polar ConceptIn Shakespeare's Hamlet. Global

Journal of Human Social Science, 12, 19-23.

Manto, S. H. (2015). Manto Kay Afsanay. Pakistan: Sang-e-meel.

Marzola, A. (2014). Hamlet and the Passion of Knowledge.Memoria di Shakespeare. A Journal of Shakespearean Studies, 220, 203-220.

Murphy, S. (2007). Now I am alone: A corpus stylistic approach to Shakespearian soliloquies.

Language,1, 67-85.

Searle, J.R. (1969). Speech Acts: An Essay in the Philosophy of Language. Cambridge: Cambridge University Press.

Searle, J.R. (1976). A classification of illocutionary acts. Language in Society, 5, 1-23.

Shakespeare, W.(2004).The Tragedy of Hamlet, Prince of Denmark. Retrieved from http://collegebookshelf.net.

Shibuya, Y. (2004). Hamlet's 'Globe' and the Self as Performer in England and Japan. CLCWeb: Comparative Literature and Culture, 6, 1-7.

Stearns, M.W. (1949). Hamlet and Freud.National Council of Teachers of English, 10, 265-272.

Tabatabaei, O. \&Samiee, Z. (2013). Transfer of requestive speech act from L1 to L2in Iranian EFL learners. Procedia-Social and Behavioral Sciences, 70, 239-244.

Wouk, F. (2006).The language of apologizing in Lombok, Indonesia.Journal of Pragmatics, 38, 1457-1486.

Yıldırım, A. \&Şimşek, H. (2005).Qualitative research methods in social sciences. Ankara: Seçkin Publishing.

Yinghui, H. U. (2015). Random Comments on the Character of Hamlet.Studies in Literature and Language, 11, 66-70. 